Publisher Correction

\title{
Correction to: Some Restricted Lindenbaum Theorems Equivalent to the Axiom of Choice
}

David W. Miller

Correction to: Log. Univers. 1 (2007), 183-199 https://doi.org/10.1007/s11787-006-0009-0

The publisher would like to confirm that the author owns the copyright of the article. The PDF version of the article shows the correct copyright ownership, but in XML it was indicated wrongly. The copyright ownership has been corrected in the XML. The publisher regrets the inconvenience caused.

(C) Copyright D.W. Miller 2000, 2007. All rights reserved.

Publisher's Note Springer Nature remains neutral with regard to jurisdictional claims in published maps and institutional affiliations.

David W. Miller

Department of Philosophy

University of Warwick

Coventry CV4 7AL

UK

e-mail: d.w.miller@warwick.ac.uk

The original article can be found online at https://doi.org/10.1007/s11787-006-0009-0. 